UDC 378.147: 378.14

DOI https://doi.org/10.31392/NPU-nc.series5.2021.81.12

Holubova $\boldsymbol{H} . \boldsymbol{V}$.

\title{
PHD STUDENTS' FOREIGN LANGUAGE STUDIES IN THE EDUCATIONAL SPACE OF HIGHER SCHOOL
}

The article is devoted to the PhD students' foreign language teaching in the educational space of higher educational institution. The analysis of the scientific fund on the research subject substantiated that modern higher school is an educational and cultural center that acts as a special educational space defining the vectors of personal and professional self-determination and self-development. Thereby, the organization of educational process in the higher school should be based on the principles of scientific, cognitive, information and methodological support, which contribute to the acquired knowledge comprehension, as well as stimulate creative research activities at all higher education levels. The content of the educational space was characterized. It was established that in the process of PhD students'foreign language training it is advisable to use such learning technologies, as: developmental, problem-searching, functional, information-developmental, personality-oriented. Based on the theoretical analysis of the psychological and pedagogical literature, it was determined, firstly, that the educational space is characterized by the availability of at least two dimensions: objective and subjective; secondly, in the process of PhD students'foreign language training such tasks are implemented, as developmental, communicative, cognitive, which contribute to the advancement of the following skills: fluent reading; capability of translating authentic foreign texts; ability to shape the information received from foreign sources in the form of translation, review, annotation; capability to communicate in a foreign language in a professional and scientific environment; to perform written scientific communication on the theme of dissertation research; possession of speech etiquette in scientific communication; ability to perform logical operations; thirdly, the training should be based on such principles, as: systematicity and consistency, accessibility, connection with life, emotionality, usage of authentic materials, involvement of professional disciplines teachers in joint teaching and research activities, interdisciplinary approach, integrity of educational, scientific and practical activities, etc.

Key words: educational space, PhD students (postgraduate students), foreign language training, communication skills, intercultural scientific communication.

The preparation of candidates for the degree of Doctor of Philosophy requires due attention to the issues of language education, further development of foreign language communicative competence and preparation for intercultural communication. Since foreign language proficiency is an integral part of social development in modern times, especially significant is further improvement of theoretical and practical aspects of foreign language education for $\mathrm{PhD}$ students, which will promote effective foreign language mastery as a means of intercultural and professional communication in various fields of scientific activity.

The main purpose of teaching a foreign language in postgraduate school is to achieve a level of practical language proficiency, which provides scientist' communicative independence in the fields of vocational and academic communication in oral and written forms, allows its appliance in the research and professional activities, promotes the development of a creative personality capable of self-development and self-improvement. Therefore, the problem of creating a favorable educational space as the most viable form of organizing the PhD students' effective training is of high priority.

Numerous scientists have devoted their research to various aspects of the $\mathrm{PhD}$ students' foreign language training, including theoretical, methodological and practical issues on teaching a foreign language in postgraduate school of non-linguistic institutions of higher education (G. Buyanova, O. Peunova, T. Popova, M. Fedotova, $\mathrm{O}$. Yaroslavova), to the investigation of the features of organizing $\mathrm{PhD}$ students' individual work in the process of learning a foreign language (A. Kinderknecht, L. Pelekh, N. Shumakova). Such scholars as E. Bondarevska, N. Borytko, A. Gavrilin, S. Gershunsky, D. Grigoriev, I. Kolesnikova, Yu. Manuilov, A. Mudryk, L. Novikova, N. Rybka, N. Selivanova, I. Shalayev, G. Shcheveleva, V. Slobodchikov, A. Veryaev, M. Vilensky, V. Yasvin and others devoted their research to the investigation of various aspects of the educational space.

Despite the considerable attention turned to this problem, it needs further research due to the fact that contemporaneity poses difficult and sometimes controversial tasks as regards to organizing the educational process under the conditions of increasing demands upon the degree of training the third-level higher education applicants. In the process of training $\mathrm{PhD}$ students there is a reguirement to take into account, first of all, the peculiarities of the educational space of institution of higher education they study in.

The aim of the article is to consider the peculiarities of the $\mathrm{PhD}$ students' foreign language training in the educational space of higher school.

The main direction of a modern higher school development is creating conditions for personal and professional progress of the future specialist, who should possess a high level of general and professional competence, navigate firmly through modern educational space and use its resources for self-development and self-improvement. The main content of higher educational institutions activity at the present time is the formation of educational space, which contributes to the comprehensive development of the future specialist' personality, as well as to the formation of his / her professional and foreign language competence. In this regard, the organization of the educational process 
in institutions of higher education should be based on the principles of scientific, cognitive, information and methodological support, which contribute to comprehension of the knowledge acquired, as well as stimulates creative research activities of higher education applicants.

Doctor of Philosophy is the first scientific degree obtained at the third level of higher education on the basis of Master's degree. The main form of training for the degree of Doctor of Philosophy at the third (educational and scientific) level of higher education is postgraduate school. Postgraduate studies are the continuation of the classical system of professional education of lower levels, involving its basic characteristics with the priority of scientific activity.

Studying at the third educational level and obtaining the Doctor of Philosophy degree involves not only preparation and defense of dissertation, mastering of methodological and philosophical foundations in a particular scientific field, acquiring by the applicant of higher education the skills, theoretical knowledge, abilities and other competencies sufficient for scientific research, having scientific novelty; theoretical and practical knowledge for producing new ideas, solving problems in the professional and research areas, but also for further development of foreign language communicative competence. There are requirements put forward both for practical foreign language knowledge and for its use as a means of obtaining and exchanging the necessary information, taking into account the specifics of the PhD students' studies, which involves investigation and is related to the processing of scientific information.

$\mathrm{PhD}$ students are trained according to educational and scientific programs of scientific institutions and higher educational institutions, which are developed according to the European integration processes in higher education of our country, providing for the creation of an integrative scientific space. The PhD students' training involves mastering an interconnected set of disciplines from fundamental to those directly related to the specifics of professional activity, which involves a spectra of various scientific branches. The researcher must understand the specifics of professionally oriented training. Thus, implementation of new disciplines, which are interdisciplinary, since created as a result of sciences integrity, is a prerequisite for educational and scientific training programs for PhD students.

For postgraduate students who have dedicated themselves to research, it becomes clear that high level of communication skills possession makes a significant contribution to further successful career in academia and competitiveness in the modern world, the development of the ability for self-education and self-improvement, readiness for self-development.

It is obvious that improving the quality of professional education and forming the high level of foreign language competence can be achieved only by activating all the factors that fall within the educational space of higher school. In the conditions of continuous development of society, higher educational institutions are in search of effective models of their own improvement. Regarding this, the formation of an individual trajectory for the development of the PhD students' competencies is the main guideline for the modernization of the third level of education. As to the educational space of the university, it should not only be adequate to the needs of the real sector in vocational training at appropriate professional and cultural levels, but also be flexible, able to respond to the professional reality and provide a high level of training professionals who create and apply professional culture standards. The task of a modern higher educational institution is not only to provide knowledge advancement, but to combine education, science and innovation, promote the state's integration into the world educational and scientific space.

Educational space is characterized by the amount of educational services, capacity and intensity of educational information, educational infrastructure of society [5]. Educational space is identified by at least two dimensions: objective and subjective. The objective dimension is represented by the really existing elements of a specially formed educational space, represented by social conditions, information and legislative support, individual educational systems with their programs and events that actually exist and have their impact on a particular subject of the educational process to a certain (greater or lesser) extent. The subjective dimension is introduced by those elements of the educational space that exist virtually in the human mind; it is the space of yet unrealized norm, the ideal, which exposes the connection with the reality also to a certain (greater or lesser) extent [5].

The educational space of higher school reflects the peculiarities of constructing interpersonal interaction between the subjects of the educational process. Achieving of the abovementioned objectives of effective interaction is provided by constructing of such an educational space of higher school, which involves the development and implementation of learning technologies based on the strategies of enrichment, complexity of educational content, widening, intensifying PhD students' educational activities. Planning, selecting the forms and types of postgraduate students' activities in foreign language classes should be a flexible process of adaptation to the external factors changes. Thus, in the context of PhD students' foreign language training not only the final result is important, but also the process of acquiring knowledge, developing skills to independently resolve cognitive, exploratory tasks, the solution of which leads to the formation of the skills for successful research.

Postgraduate education is aimed at the development of creative skills that promote activeness, production of original ideas, application of a creative approach to problems solving. Purposeful creation of an appropriate space in the higher school is possible only on the basis of interaction and cooperation, so an important role is played by the active search and collaborative creativity of teachers and $\mathrm{PhD}$ students, their interest in achieving the results, successful activities on the formation of a comprehensively developed personality of the higher education applicant, who is involved in an active creative educational process. $\mathrm{PhD}$ student's motivation for scientific research work is formed mainly by the teacher - a scientist who has mastered the methodology and technology of scientific knowl- 
edge, who encourages the postgraduate students to independently search for the scientific truth. The organization of any work, including individual, independent scientific research of the postgraduate student, is based on the activities that are directed and controlled by the teacher. The most effective solution to the pedagogical tasks of the university educational space offers the democratic style of teaching guidance, which takes into account individual characteristics of higher education applicants, their personal experience, the specifics of their needs and capabilities, provides for the deepening of theoretical and practical training for scientific and pedagogical activities and scientific consulting in the field of education, the development of research skills for independent investigations, training and research in the field of education.

Foreign language studies in postgraduate school are aimed at improving the knowledge and skills of working with scientific discourse, acquaintance with grammatical and lexical features of the scientific and technical literature style, syntactic means in scientific and technical texts; improving of scientific-written and scientific-business communication skills, readiness for effective translation of scientific and technical foreign literature, improving the ability to communicate in a foreign language in the professional and scientific environment [1, p. 491].

The process of foreign language training of the $\mathrm{PhD}$ students should be aimed at organizing their proactive educational and cognitive activities, i.e. the development of abilities and skills to acquire knowledge independently [3]. The following learning technologies are considered effective in the process of the postgraduate students' foreign language training: information-developmental (aimed at the development of erudition and foreign language knowledge), functional (consisting in the development of a specialist capable of solving professional tasks using a foreign language), developing problem-searching (aimed at the development of postgraduate students' mental activity), personality-oriented technologies (associated with the formation of an active personality capable of organizing his / her professional and educational activities) [4, p. 51-53].

The result of the $\mathrm{PhD}$ students' foreign language training should be the demonstration of a high level of professionally oriented intercultural communicative competence. In the process of achieving this goal, the communicative, cognitive and developmental tasks are implemented, which contribute to the development of the following skills: read fluently foreign language scientific texts in the chosen specialty; translate authentic foreign texts on a topic related to the $\mathrm{PhD}$ student' sphere of scientific interests, proficiently use the knowledge of terminology, grammatical structures, methods of translation transformations; arrange the information received from foreign sources in the form of a translation, review, annotation; communicate in a foreign language in a professional and scientific environment (reports, presentations, round tables, discussions, participation in conferences, etc.); written scientific communication on the topic of dissertation research (annotations, abstracts, scientific articles, academic essays); effectively master the speech etiquette of scientific communication; perform logical operations (analysis, synthesis, argumentation, generalization, conclusions, commenting) [1, p. 489].

Of particular importance is the issue of creating a favorable educational space as the most viable form of organizing the effective future professionals' training. The higher educational institution should provide the effective educational, cognitive, research and practical work of the $\mathrm{PhD}$ students, give ample opportunities for self-expression and self-assertion, characterized by maturity and the tendency for self-development.

The development of foreign language communication skills of all the levels graduates at non-language specialties of a modern higher educational institution should be based on the principles of systematicity and consistency, accessibility, connection with life, emotionality, usage of authentic materials, involvement of professional disciplines teachers in joint research and teaching activities, interdisciplinary approach, integrity of educational, scientific and practical activities, individual approach while working with $\mathrm{PhD}$ students, personal significance, free choice, consciousness and activeness, adaptation to the changes in external factors [2].

Knowledge of a foreign language is a factor in promoting a number of professional competencies development, as they provide awareness in various aspects of professional activities, which is ensured by the ability to extract, analyze, process, generate and use information in a foreign language. Moreover, active promoting of scientific developments at the international level is associated with the ability to present the results of their research in the form of the reports at international conferences, seminars; scientific publications (including publications in the Web of Science, Scopus indexed journals), etc. [6].

Thus, taking into account the influence of educational space of the higher school on $\mathrm{PhD}$ students' foreign language communicative competence, its goal-oriented formation is an important issue in modern science.

Conclusions. A complex multifaceted formation, covering a set of external factors (in which the educational activities are implemented, active educational processes and relationships are performed), is the educational space of higher school, the main purpose of which is to stimulate maximum potential and professional development of a higher education applicant. The main purpose of teaching a foreign language in postgraduate school is to achieve a level of practical language proficiency, which allows its use in professional activities and research, provides the scientist's communicative independence in the field of professional and academic communication in verbal and written forms.

The prospects for further research in this area are seen in classifying the methods of foreign language teaching to the PhD students, taking into account the impact of the educational space of higher school. 


\section{Bibliography:}

1. Духаніна Н. М. Особливості навчання іноземних мов здобувачів вищої освіти ступеня доктора філософії (PhD). Молодий вчений. 2018. № 4 (2). С. 489-492.

2. Золотова С. Г., Міхно С. В. Розвиток навичок іншомовної комунікації студентів та аспірантів. Вісник Глухівського національного педагогічного університету імені Олександра Довженка. 2017. Вип. 34. С. 93-101.

3. Кузнецов И. А. Иноязычная подготовка аспирантов в системе непрерывного образования технического вуза. Среднее профессиональное образование. 2015. № 4. С. 48-50.

4. Обучение иностранному языку в аспирантуре неязыкового вуза : актуальные вопросы : монография / Г. В. Буянова, А. С. Киндеркнехт, Т. В. Попова, Е. В. Пеунова; науч. ред. А. С. Киндеркнехт; М-во с.-х. РФ, федеральное гос. бюджетное образов. учреждение высшего образования “Пермская гос. с.-х. акад. им. акад. Д. Н. Прянишникова". Пермь : ИПЦ “Прокростъ”, 2017. 188 с.

5. Шалаєв И. К., Веряев А. А. От образовательных сред к образовательному пространству : понятие, формирование, свойства. Педагог. 1999. № 4. С. 73-84.

6. Ярославова Е. Н., Федотова М. Г. Концепция непрерывного профессионально-ориентированного иноязычного образования как условие самореализации будущего специалиста высшей квалификации. Челябинск : Издательский центр ЮУрГУ, 2010. $316 \mathrm{c}$

\section{References:}

1. Dukhanina N. M. Osoblyvosti navchannya inozemnykh mov zdobuvachiv vyshchoyi osvity stupenya doktora filosofiyi (PhD) [Features of teaching foreign languages to the graduates of the Doctor of Philosophy degree (PhD)]. Molodyy vchenyy. 2018. № 4 (2). S. 489-492. [in Ukrainian]

2. Zolotova S. H., Mikhno S. V. Rozvytok navychok inshomovnoyi komunikatsiyi studentiv ta aspirantiv [Development of foreign language communication skills of students and postgraduate students]. Visnyk Hlukhivs'koho natsional'noho pedahohichnoho universytetu imeni Oleksandra Dovzhenka. 2017. Vyp. 34. C. 93-101. [in Ukrainian]

3. Kuznetsov I. A. Inoyazychnaya podgotovka aspirantov v sisteme nepreryvnogo obrazovaniya tekhnicheskogo vuza [Foreign language training of postgraduate students in the system of continuous education of a technical university]. Sredneye professional'noye obrazovaniye. 2015. № 4. S. 48-50. [in Russian]

4. Obucheniye inostrannomu yazyku v aspiranture neyazykovogo vuza : aktual'nyye voprosy : monografiya [Teaching a foreign language in postgraduate school of a non-linguistic university : topical issues : monograph] / G. V. Buyanova, A. S. Kinderknekht, T. V. Popova, Ye. V. Peunova; nauch. red. A. S. Kinderknekht; M-vo s.-kh. RF, federal'noye gos. byudzhetnoye obrazov. uchrezhdeniye vysshego obrazovaniya "Permskaya gos. s. kh. akad. im. akad. D. N. Pryanishnikova". Perm' : IPTS “Prokrost"”, 2017. 188 s. [in Russian]

5. Shalaêv I. K., Veryayev A. A. Ot obrazovatel'nykh sred k obrazovatel'nomu prostranstvu: ponyatiye, formirovaniye, svoystva [From educational environments to the educational space : concept, formation, properties]. Pedagog. 1999. № 4. S. 73-84. [in Russian]

6. Yaroslavova Ye. N., Fedotova M. G. Kontseptsiya nepreryvnogo professional'no-oriyentirovannogo inoyazychnogo obrazovaniya kak usloviye samorealizatsii budushchego spetsialista vysshey kvalifikatsii [The concept of continuous professionally-oriented foreign language education as a condition for self-realization of a future higher qualification specialist]. Chelyabinsk : Izdatel'skiy tsentr YUUrGU, 2010. 316 s. [in Russian]

\section{Голубова Г. В. Іншомовна підготовка аспірантів в освітньо-виховному просторі закладу вищцї освіти}

Статтю присвячено іншомовній підготовці аспірантів в освітньо-виховному просторі закладу вищої освіти. Здійснений аналіз наукового фонду з предмета дослідження надав змогу встановити, щэо сучасний заклад вищоі освіти є освітньо-культурним иентром, який виступає особливим освітньо-виховним простором, щео визначає вектори особистісного та професійного самовизначення й саморозвитку особистості. 3 огляду на ие організація навчально-виховного процесу у вищій школі має базуватися на принщипах наукового, пізнавального, інформаційного та методичного забезпечення, щзо сприяє осмисленню отриманих знань, а також стимулює творчу науково-дослідну діяльність здобувачів вищої освіти всіх рівнів. Охарактеризовано змістовне наповнення конструкту "освітньо-виховний простір”. Встановлено, що у проиесі іншомовної підготовки аспірантів доиільно використовувати такі технологї навчання, як: розвивальні, діяльнісні, проблемно-пошукові, інформаційно-розвивальні, особистісно-орієнтовані. На основі теоретичного аналізу психолого-педагогічної літератури визначено, щьо, по-перше, освітній простір вирізняється наявністю щуонайменше двох вимірів: об'єктивного і суб'єктивного; по-друге, у процесі іншомовної підготовки аспірантів реалізуються розвивальні, комунікативні, когнітивні завдання, які сприяють розвитку наступних умінь: вільно читати; перекладати автентичні іншомовні тексти; оформлювати отриману з іноземних джерел інформацію у вигляді перекладу, огляду, анотації; здійснювати комунікацію іноземною мовою у професійному та науковому середовищі; умінь письмового наукового спілкування за темою дисертаційного дослідження; навичок мовленнєвого етикету наукового спілкування; вміння здійснювати логічні операції; по-третє, така підготовка повинна трунтуватися на наступних принципах: системності та послідовності, доступності, зв 'язку з життям, емоиійності, використання аутентичних матеріалів, залучення викладачів фахових дисииплін до спільної науково-викладацької діяльності, міждисциплінарного підходу, єдності навчальної, наукової та практичної діяльності тощз.

Ключові слова: освітньо-виховний простір, аспіранти (здобувачі вищої освіти третього рівня), іншомовна підготовка, комунікативні вміння, міжкультурна наукова комунікація. 